\title{
Influence of the type of housing on the intestinal microflora of layers and broilers
}

\author{
Maria Mazanko ${ }^{1 *}$, Eugenia Prazdnova ${ }^{1}$, Anjelika Bren $^{1}$, Dmitriy Rudoy ${ }^{1}$, and Arkady \\ Babajanyan $^{1}$ \\ ${ }^{1}$ Don State Technical University, Gagarin square 1, Rostov-on-Don, 344000, Russia
}

\begin{abstract}
The microbiota of birds of different housing types was studied, namely: cage, outdoor and free-range. The number of bacteria Lactobacillus, Bifidobacterium, Enterococcus, E. coli and lactose-positive, Bacillus in bird faeces was investigated. It has been shown that the composition of the microbiota does not depend on the type of their content but depends on the type of nutrition and on the microbiota that was initially located in a farm or poultry house environment. At the same time, the microbiota of birds can change at a young age, but after puberty, it becomes more stable. The microbiota of free-range birds remained stable while maintaining diet and changed with diet changes depending on the season. It has also been shown that litter and soil are capable of retaining significant numbers of intestinal bacteria. Bacillus can colonize birds' gut, but it is not a permanent participant in the gut microbiota of birds.
\end{abstract}

\section{Introduction}

Currently, the poultry industry is one of the largest agricultural sectors. Chickens make up the bulk of both meat and egg production $[1,2]$.

An important parameter affecting a bird's productivity is its health status, and the intestinal microbiota makes a considerable contribution to this parameter. It has been shown that the intestinal microbial community affects the immune system [3,4], the level of oxidative stress [5], DNA stability [6], weight and growth rate [7], as well as egg production [8] of birds. Therefore, the state of the intestinal microflora must be strictly controlled in factories and subsidiary farms.

It is known that a significant number of factors influences the intestinal microflora: the quality and composition of feed [9, 10], the use of medicinal substances [11, 12], and the state of the host's organism [13], which, in turn, is influenced by factors such as temperature, humidity, day length, etc. [14 - 16]. Therefore, the conditions in which the bird is kept can directly affect the intestinal microbiota state.

In factories, birds are most often kept in cages (cage housing) or pens on a bedding layer (floor housing). In subsidiary farms, the free-range type of housing, when the bird is kept in the poultry house and has a fenced-in area for walking, is most often used.

\footnotetext{
* Corresponding author: mmazanko@,sfedu.ru
} 


\section{Materials and methods}

\subsection{Examined birds}

The study involved poultry belonging to meat and egg breeds of different types of housing. Their characteristics, as well as the characteristics of feeds, are presented below. It should be noted that factories often keep birds of different ages. In this case, samples were taken from birds of all ages available at the moment. Since changing environmental conditions can affect birds, samples from free-range chickens, if possible, were taken twice at the same point: in the winter and summer seasons.

1. Egg cross Hisex-brown, cell housing; age: 200, 300, 500 days; feed: standard feed mixture; CJSC Gulyai-Borisovskaya Poultry Farm, h. Gulyai-Borisovka, Zernogradsky district, Rostov region.

2. Egg cross Hisex-brown, cell housing, age: 15, 30, 170, 200, 300, 370 days; feed: standard feed mixture; OJSC "Poultry farm Belokalitvinskaya", p. Sosny, Belokalitvinskaya district, Rostov region.

3. Foor- housing broilers, cross Cobb, age: 14 days, 42 days; feed: complete feed; poultry farm "Donetsk broiler" (IE Stroitelev ON), Donetsk, Rostov region.

4. Cage housing broilers, cross Cobb, age: 38 days; feed: complete feed; DSTU educational farm, RO;

5. Egg cross Hisex-brown, free-range housing, seasons: winter, summer; feed: compound feed PK-1-2; private subsidiary farm, settlement Persianovskiy, Oktyabrskiy district, Rostov region.

6. Egg breed striped leghorn, free-range housing, seasons: winter, summer; feed: complete feed with additives in the form of vegetables up to $20 \%$, in summer - up to $30 \%$ of the diet; private subsidiary farm, v. Razdolnoe, Krasnodar Territory.

7. Egg cross Hisex-brown, free-range housing, seasons: winter, summer; feed: Megamix mixed feed with vegetable additives up to $10 \%$, in summer - up to $30 \%$ of the diet; private subsidiary farm, Rostov-on-Don.

8. Hisex-brown egg cross, free-range housing, seasons: winter; feed: a grain of spring wheat $25 \%$, spring barley $25 \%$, soybean meal $15 \%$, peas $10 \%$, wheat bran $15 \%$, chickpea $10 \%$ with meat and bone admixtures and fish meal as additives; Turkey, Samsun.

All chickens did not receive any pre- or probiotic supplements in either feed or bedding additives. Also, all chickens did not receive antibiotics for at least six months before starting the study.

\subsection{Sampling}

Fresh litter obtained from healthy birds was selected. The faeces of 5 to 6 birds were taken and placed in sterile plastic containers. The sample volume was 30-40 g.

The litter selection was carried out at different points in the room, at least five different points. The selection was made in a plastic container. Sample volume - 100-150 g.

The soil was sampled in the centre of the walking area using the "envelope" method. The soil was sampled at the corners of a square with a side of $1 \mathrm{~m}$ and in the centre of this square, from a depth of 0-5 cm into a plastic container. Sample volume $-150-200 \mathrm{~g}$.

All samples were cooled to $+4^{\circ} \mathrm{C}$ and within one day delivered to the laboratory. During transportation, to ensure the maintenance of low temperatures, cooler bags were used. 


\subsection{Determination of moisture}

The litter and soil were weighed, then placed in an oven and dried for 6 hours at a temperature of $105^{\circ} \mathrm{C}$. After drying, the litter and soil were re-weighed and the $\%$ moisture calculated.

\subsection{Microbiota research}

Inoculation was carried out strictly on the day of the transfer of samples to the laboratory. Each sample was thoroughly mixed. Then, two portions of $10 \mathrm{~g}$ were taken from each sample. A series of successive decimal dilutions in physiological solution was made; the second portion was placed in a sterile container and left in the refrigerator for $48 \mathrm{~h}$.

The study was carried out using surface inoculation in the amount of 3 replicates for each nutrient medium for each test dilution. The study of the number of bifidobacteria was carried out by inoculating a suspension into a semi-liquid nutrient medium.

To determine the number of Lactobacillus bacteria, we used MRS medium (LenReaktiv), for Bifidobacterium - medium for the isolation of bifidobacteria (HiMedia), for Enterococcus - medium for isolation of enterococci (HiMedia), for E. coli and lactosepositive (Citrobacter, Enterobacter) bacteria - medium Endo HiMedia).

Then they were incubated in an anaerobic station Bactrone, Shel Lab, USA, at a temperature of $42^{\circ} \mathrm{C}$ (bird body temperature [17]). After 48 hours of incubation, the grown colonies were counted.

To isolate bacteria p. Bacillus samples after being at $+4{ }^{\circ} \mathrm{C}$ for 48 hours (before the formation of spores [18]) were diluted with saline in a ratio of 1:10 and placed in a water bath, where they were heated to a temperature of $93-95^{\circ} \mathrm{C}$ for three minutes. During this time, all microorganisms in the sample died, except for bacilli spores. A series of successive dilutions were then made and sown superficially on solid nutrient medium MPA (LenReaktiv). Colonies were incubated for $24 \mathrm{~h}$ at $42^{\circ} \mathrm{C}$ and then counted.

\subsection{Statistical analisys}

Data statistical analysis was conducted using Student's t-test. Differences were considered statistically significant at $\mathrm{p}<0.05$.

\section{Results and discussion}

Table 1 shows the results of a study of the microbiota of the egg cross Hisex-brown cell containment of ZAO Gulyai-Borisovskaya Poultry Farm, h. Gulyai-Borisovka, Zernogradskiy district.

Table 1. Microbiota of hens of cellular housing, CJSC "Gulyai-Borisovskaya Poultry Farm", CFU/g.

\begin{tabular}{|c|c|c|c|c|c|c|}
\hline $\begin{array}{c}\text { Groups of } \\
\text { microorganisms }\end{array}$ & 15 days & 30 days & 170 days & 200 days & 300 days & 370 days \\
\hline Lactobacillus & $1,1 \pm 0,1 \cdot 10^{6}$ & $3,7 \pm 0,3 \cdot 10^{6}$ & $1,8 \pm 0,2 \cdot 10^{8}$ & $3,1 \pm 0,1 \cdot 10^{8}$ & $2,0 \pm 0,1 \cdot 10^{8}$ & $2,2 \pm 0,6 \cdot 10^{8}$ \\
\hline Enterococcus & $\begin{array}{c}2,8 \pm 0,08 \cdot 1 \\
0^{7}\end{array}$ & $5,1 \pm 1,7 \cdot 10^{7}$ & $1,5 \pm 0,3 \cdot 10^{6}$ & $2,0 \pm 0,2 \cdot 10^{6}$ & $1,9 \pm 0,6 \cdot 10^{6}$ & $2,0 \pm 0,3 \cdot 10^{6}$ \\
\hline Bifidobacterium & $10^{4}$ & $10^{6}$ & $10^{6}$ & $10^{6}$ & $10^{6}$ & $10^{6}$ \\
\hline $\begin{array}{c}\text { E.coli } \\
\text { Coliform } \\
\text { bacteria }\end{array}$ & $\begin{array}{c}4,0 \pm 1,0 \cdot 10^{7} \\
6,1 \pm 0,1 \cdot 10^{7}\end{array}$ & $\begin{array}{c}7,5 \pm 0,01 \cdot 1 \\
0^{7} \\
3,0 \pm 0,1 \cdot 10^{6}\end{array}$ & $\begin{array}{c}2,3 \pm 0,08 \cdot 10^{6} \\
2,1 \pm 0,1 \cdot 10^{6}\end{array}$ & $\begin{array}{c}1,9 \pm 0,2 \cdot 10^{6} \\
8,9 \pm 0,4 \cdot 10^{5}\end{array}$ & $\begin{array}{c}2,4 \pm 0,2 \cdot 10^{6} \\
5,5 \pm 0,8 \cdot 10^{5}\end{array}$ & $\begin{array}{c}1,3 \pm 0,7 \pm 0,3 \cdot 10^{6} \\
4,7\end{array}$ \\
\hline Bacillus & - & - & - & - & - & - \\
\hline
\end{tabular}


At the poultry farm, birds of different ages were presented, all ages available at the time of selection were examined. It should be noted that starting from the age of 170 days, the microflora of birds practically did not differ from each other, retaining the number and proportions of various groups of microorganisms. At the same time, the microbiota in young birds was significantly different $(\mathrm{p}<0.05)$ from adults.

Table 2 shows the results of a study of the microbiota of the egg cross Hisex-brown chickens, cell housing, JSC "Poultry farm Belokalitvinskaya", p. Sosny, Belokalitvinsky district.

Table 2. Microbiota of hens of cellular housing, JSC "Poultry farm Belokalitvinskaya", CFU/g.

\begin{tabular}{|c|c|c|c|}
\hline $\begin{array}{c}\text { Groups of } \\
\text { microorganisms }\end{array}$ & 200 days & 300 days & 500 days \\
\hline Lactobacillus & $4,4 \pm 0,4 \cdot 10^{6}$ & $7,9 \pm 0,7 \cdot 10^{6}$ & $5,1 \pm 0,4 \cdot 10^{6}$ \\
\hline Enterococcus & $2,6 \pm 0,04 \cdot 10^{6}$ & $6,4 \pm 0,1 \cdot 10^{6}$ & $2,0 \pm 0,2 \cdot 10^{6}$ \\
\hline Bifidobacterium & $10^{4}$ & $10^{4}$ & $10^{4}$ \\
\hline E.coli & $7,2 \pm 0,03 \cdot 10^{5}$ & $2,7 \pm 0,3 \cdot 10^{5}$ & $3,7 \pm 0,04 \cdot 10^{5}$ \\
Coliform bacteria & $5,6 \pm 0,2 \cdot 10^{6}$ & $3,5 \pm 0,1 \cdot 10^{6}$ & $3,9 \pm 0,1 \cdot 10^{6}$ \\
\hline Bacillus & $1,1 \pm 0,07 \cdot 10^{5}$ & $2,5 \pm 0,09 \cdot 10^{5}$ & $1,7 \pm 0,07 \cdot 10^{5}$ \\
\hline
\end{tabular}

At the time of sampling, the poultry farm contained birds of three ages, all of which began laying eggs. In this case, birds' microbiota also did not differ significantly from each other; the number of microorganisms of the same group at different ages was within the same order.

At the same time, the number of lactobacilli and bifidobacteria was two orders of magnitude lower than that of chickens of ZAO Gulyai-Borisovskaya Poultry Farm, which may have a harmful effect on the health of the bird [19, 20,22].

A reasonably large number of spore-forming bacteria Bacillus $\left(1.1 \pm 0.07 \cdot 10^{5}-2.5 \pm\right.$ $0.09 \cdot 10^{5} \mathrm{CFU} / \mathrm{g}$ ) was observed in the microbiota of chickens of OJSC Poultry Farm Belokalitvinskaya. Morphologically, four types of colonies were distinguished, coinciding from sample to sample, which gives us the right to assume that these bacilli are an integral part of the microbiota of birds of this poultry farm [23,24].

Table 3 shows the results of a study of the microbiota of broilers of the Cobb cross of cell content, educational farm DSTU, RO, feed: complete.

Table 3. Microbiota of broilers of cell content, the educational farm of DSTU, CFU/g.

\begin{tabular}{|c|c|c|}
\hline Groups of microorganisms & 14 days & 42 days \\
\hline Lactobacillus & $1,5 \pm 0,2 \cdot 10^{9}$ & $1,2 \pm 0,2 \cdot 10^{9}$ \\
\hline Enterococcus & $7,7 \pm 0,9 \cdot 10^{6}$ & $2,3 \pm 0,1 \cdot 10^{6}$ \\
\hline Bifidobacterium & $10^{7}$ & $10^{7}$ \\
\hline E.coli & $4,1 \pm 0,9 \cdot 10^{7}$ & $5,1 \pm 0,4 \cdot 10^{7}$ \\
Coliform bacteria & - & $3,0 \pm 0,4 \cdot 10^{5}$ \\
\hline Bacillus & - & - \\
\hline
\end{tabular}

Broilers of cage housing were also at the DSTU educational farm at two ages - twoweek-old chickens and poultry before slaughter. Their microbiota differed among themselves in the coliform group: only E. coli was determined in young animals, while other lactose-positive bacteria were also observed in adult birds.

In general, the birds had high levels of probiotic bacteria: lacto- and bifidobacteria.

Table 4 shows the results of a study of the microbiota of broilers of the Cobb cross of floor housing, poultry farm "Donetsk broiler" (IE Stroitelev ON), feed: complete. 
Table 4. Microbiota of floor housing broilers, Donetsk Broiler poultry farm, CFU/g.

\begin{tabular}{|c|c|c|}
\hline Groups of microorganisms & Faecal samples & Litter \\
\hline Lactobacillus & $8,0 \pm 0,5 \cdot 10^{8}$ & $1,2 \pm 0,2 \cdot 10^{7}$ \\
\hline Enterococcus & $1,2 \pm 0,05 \cdot 10^{6}$ & $2,7 \pm 0,6 \cdot 10^{6}$ \\
\hline Bifidobacterium & $10^{8}$ & $10^{6}$ \\
\hline E.coli & $4,0 \pm 1,0 \cdot 10^{7}$ & $7,1 \pm 0,4 \cdot 10^{6}$ \\
Coliform bacteria & $1,3 \pm 0,6 \cdot 10^{6}$ & $1,8 \pm 0,5 \cdot 10^{6}$ \\
\hline Bacillus & $1,5 \pm 0,5 \cdot 10^{4}$ & $2,9 \pm 0,3 \cdot 10^{6}$ \\
\hline
\end{tabular}

The microbiota of broilers (38 days) of the poultry farm "Donetsk Broiler" was distinguished by a high number of lactobacilli and bifidobacteria. In contrast, the number of lactobacilli was an order of magnitude lower than in the DSTU educational farm, and bifidobacteria - an order of magnitude higher. In contrast to the previous group of broilers, these birds' microbiota contained $1.5 \pm 0.5 \cdot 10^{4} \mathrm{CFU} / \mathrm{g}$ of bacilli. 4 types of colonies were distinguished morphologically. Microbiota of adult birds of floor and cage housing broilers significantly $(\mathrm{p}<0.05)$ differed from each other.

Litter samples were also taken from floor housing birds.

Lactobacilli were found in the litter, the number of which was an order of magnitude less than in the droppings, apparently due to the action of oxygen and drying (litter moisture $32 \%$ ). Also, the number of bifidobacteria decreased by two orders of magnitude, most likely for the same reasons. The number of E. coli also decreased. The number of enterococci has not changed.

The amount of Bacillus was two orders of magnitude larger than in the faecal samples, and the morphology of the colonies was much more diverse. Most likely, these are freeliving bacilli, the high abundance of which in the litter is supported by available organic matter from the faeces.

In general, the number of groups of intestinal microorganisms was well preserved in the litter, which is essential considering the possibility of repeated pecking of microorganisms by birds.

Table 5 shows the results of a study of the microbiota of birds of the egg cross Hisexbrown free-range housing birds, private subsidiary farm, Persianovskiy village, Oktyabrskiy district.

Table 5. Microbiota of free-range birds, personal subsidiary farm, Persianovskiy village, Oktyabrskiy district, $\mathrm{CFU} / \mathrm{g}$.

\begin{tabular}{|c|c|c|c|}
\hline $\begin{array}{c}\text { Groups of } \\
\text { microorganisms }\end{array}$ & Faecal samples & Litter & Soil \\
\hline \multicolumn{4}{|c|}{ Winter } \\
\hline Lactobacillus & $4,4 \pm 1,2 \cdot 10^{8}$ & $4,2 \pm 0,5 \cdot 10^{8}$ & $4,6 \pm 0,5 \cdot 10^{7}$ \\
\hline Enterococcus & $7,0 \pm 0,3 \cdot 10^{7}$ & $6,4 \pm 0,4 \cdot 10^{7}$ & $9,4 \pm 1,1 \cdot 10^{8}$ \\
\hline Bifidobacterium & $\geq 10^{9}$ & $10^{6}$ & $10^{6}$ \\
\hline \multicolumn{3}{|c|}{ Summer } \\
E.coli & $6,0 \pm 0,2 \cdot 10^{7}$ & $5,2 \pm 0,2 \cdot 10^{7}$ & $5,8 \pm 0,3 \cdot 10^{7}$ \\
Coliform bacteria & $2,3 \pm 0,5 \cdot 10^{6}$ & $1,7 \pm 0,3 \cdot 10^{8}$ & $3,8 \pm 0,7 \cdot 10^{7}$ \\
\hline Bacillus & $1,5 \pm 0,5 \cdot 10^{5}$ & $6,2 \pm 0,2 \cdot 10^{7}$ & $6,1 \pm 0,2 \cdot 10^{7}$ \\
\hline \multicolumn{4}{|c|}{$4,4 \pm 0,5 \cdot 10^{6}$} \\
\hline Lactobacillus & $1,3 \pm 0,1 \cdot 10^{8}$ & $3,1 \pm 0,3 \cdot 10^{6}$ & $3,9 \pm 0,4 \cdot 10^{6}$ \\
\hline Enterococcus & $8,7 \pm 0,2 \cdot 10^{7}$ & $10^{4}$ & $2,4 \pm 0,1 \cdot 10^{6}$ \\
\hline Bifidobacterium & $\geq 10^{9}$ & $3,2 \pm 0,1 \cdot 10^{6}$ & $2,1 \pm 0,1 \cdot 10^{6}$ \\
\hline E.coli & $3,3 \pm 0,2 \cdot 10^{7}$ & $3,7 \pm 0,2 \cdot 10^{5}$ & $1,4 \pm 0,2 \cdot 10^{5}$ \\
Coliform bacteria & $4,3 \pm 0,5 \cdot 10^{6}$ & $7,7 \pm 0,2 \cdot 10^{7}$ & $7,0 \pm 0,2 \cdot 10^{7}$ \\
\hline Bacillus & $4,6 \pm 1,2 \cdot 10^{5}$ &
\end{tabular}


Sampling was carried out twice - in winter and summer, to take into account changes in the microbiota of birds caused by the changing conditions of keeping: temperature, day length, etc.

The birds of Persianovskiy village have a high content of lacto- and bifidobacteria, and enterococci. The ratio of the studied groups of microorganisms did not change depending on the season. Bacteria of the p. Bacillus was found in the amount of $1.5 \pm 0.5 \cdot 10^{5}-4.6 \pm$ $1.2 \cdot 10^{5} \mathrm{CFU} / \mathrm{g}$. Five morphological types of colonies were identified, which did not change depending on the season, which may indicate these bacteria's constant presence in the microbiota of birds.

In winter, the number of lactobacilli in the litter taken from the poultry house remained at the same level as in the litter. The same was true for enterococci and E. coli. The number of other lactose-positive microorganisms even increased, and only the number of bifidobacteria decreased by two orders of magnitude.

Simultaneously, in the summer, the number of microorganisms in the litter decreased: the number of lactobacilli decreased by two orders of magnitude, bifidobacteria - by five, enterococci and coliform bacteria - by two orders of magnitude. Differences in litter moisture can explain these variations.

During wet winter, litter moisture was $81 \%$, and during dry summer, it was $29 \%$. This factor affected the survival of microorganisms.

A significant number of intestinal microorganisms, which got there from the faeces, was also observed in the soil sampled from the bird-walking areas. In winter, soil moisture was $75 \%$, in summer $-32 \%$. It also affected the number of intestinal microorganisms in the soil - in the summer, their number was much less (see Table 5). Nevertheless, even during the dry summer, the topsoil contained a sufficient number of microorganisms to speak of their effect on birds during pecking.

A large number of morphologically different bacilli were found in the litter and soil. The content of bacilli in the soil was $6.1 \pm 0.2 \cdot 10^{7}-7.0 \pm 0.2 \cdot 10^{7} \mathrm{CFU} / \mathrm{g}$ in winter and summer, respectively. This value is high for soils [21], and it is explained by the large number of organic compounds entering the topsoil with faeces.

Table 6 shows the results of a study of the microbiota of birds of the egg cross Hisexbrown, free-range content, private subsidiary farm, p. Razdolnoe, Krasnodar Territory, feed: complete feed with additives in the form of vegetables up to $10 \%$ of the diet in winter and $30 \%$ of the diet in summer.

Table 6. Microbiota of free-range birds, personal subsidiary farm, private subsidiary farm, $\mathrm{p}$. Razdolnoe, Krasnodar region, CFU/g.

\begin{tabular}{|c|c|c|c|}
\hline $\begin{array}{c}\text { Groups of } \\
\text { microorganisms }\end{array}$ & Faecal samples & Litter & Soil \\
\hline \multicolumn{3}{|c|}{ Winter } \\
\hline Lactobacillus & $4,0 \pm 0,5 \cdot 10^{8}$ & $4,7 \pm 1,4 \cdot 10^{8}$ & $3,3 \pm 0,4 \cdot 10^{8}$ \\
\hline Enterococcus & $1,0 \pm 0,5 \cdot 10^{6}$ & $1,3 \pm 0,5 \cdot 10^{7}$ & $1,4 \pm 0,1 \cdot 10^{5}$ \\
\hline Bifidobacterium & $10^{6}$ & $10^{4}$ & $10^{4}$ \\
\hline E.coli & $1,1 \pm 0,07 \cdot 10^{6}$ & $4,2 \pm 0,9 \cdot 10^{6}$ & $3,3 \pm 0,1 \cdot 10^{4}$ \\
Coliform bacteria & $3,3 \pm 0,3 \cdot 10^{5}$ & $1,1 \pm 0,1 \cdot 10^{5}$ & $1,0 \pm 0,1 \cdot 10^{4}$ \\
\hline Bacillus & - & $8,7 \pm 0,5 \cdot 10^{6}$ & $2,8 \pm 0,4 \cdot 10^{6}$ \\
\hline \multicolumn{2}{|c|}{ Summer } & $2,6 \pm 0,3 \cdot 10^{6}$ \\
\hline Lactobacillus & $3,1 \pm 0,1 \cdot 10^{8}$ & $3,5 \pm 0,2 \cdot 10^{6}$ & $2,0 \pm 0,2 \cdot 10^{6}$ \\
\hline Enterococcus & $2,1 \pm 0,5 \cdot 10^{8}$ & $1,5 \pm 0,4 \cdot 10^{5}$ & $10^{4}$ \\
\hline Bifidobacterium & $10^{7}$ & $10^{4}$ & $1,6 \pm 0,1 \cdot 10^{4}$ \\
\hline E.coli & $5,3 \pm 0,1 \cdot 10^{7}$ & $4,2 \pm 0,3 \cdot 10^{6}$ & $5,7 \pm 0,2 \cdot 10^{4}$ \\
\hline Coliform bacteria & $3,3 \pm 0,1 \cdot 10^{6}$ & $1,1 \pm 0,1 \cdot 10^{5}$ & $9,1 \pm 0,6 \cdot 10^{6}$ \\
\hline Bacillus & - & $3,5 \pm 0,6 \cdot 10^{6}$ & \\
\hline
\end{tabular}


Free-range chickens in the village Razdolny had a relatively low number of bifidobacteria in winter (around $10^{6} \mathrm{CFU} / \mathrm{g}$ ), which increased in summer to $10^{7}$. The number of lactobacilli did not change, but the number of enterococci increased in summer by two orders of magnitude and coliform bacteria - by order of magnitude. It can be explained by the change in the diet of birds in winter and summer, in particular - the proportion of fresh vegetables and other plants in the diet. In the previous group of freerange birds, the diet did not change depending on the season, and the composition of the microbiota remained constant.

Litter moisture was approximately the same - $49 \%$ in winter and $54 \%$ in summer. As in previous cases, intestinal lactobacilli and bifidobacteria suffered the most from the decreased humidity and oxygen presence. The change in the number of enterococci was ambiguous - in the summer, their numbers decreased, and in the winter, they even increased.

Soil moisture fluctuated within the same range - 52\% in winter and $44 \%$ in summer. The trend for intestinal microbiota preservation in the soil continued, although with a decrease in the number in individual groups.

The litter and soil contained a significant amount of Bacillus $-8.7 \pm 0.5 \times 10^{6}$ and $3.5 \pm$ $0.6 \times 10^{6} \mathrm{CFU} / \mathrm{g}$, respectively, in the litter in winter and summer, and $2.8 \pm 0.4 \times 10^{6}$ and $9.1 \pm 0.6 \cdot 10^{6} \mathrm{CFU} / \mathrm{g}$ in soil. As in the previous case, this is a high indicator for soils [21] and is explained by the presence of a large amount of free organic matter. At the same time, no bacilli were found in the bird droppings. Apparently, the bacilli strains capable of colonizing the intestines and accumulating in the intestinal microbiota did not enter this group of birds' intestines.

Table 7 shows the results of a study of the microbiota of birds of the egg breed stripedmotley leghorn of free-range content, personal subsidiary farm, Rostov-on-Don.

Table 7. Microbiota of free-range birds, personal subsidiary farm, personal subsidiary farm, Rostovon-Don, CFU/g.

\begin{tabular}{|c|c|c|c|}
\hline $\begin{array}{c}\text { Groups of } \\
\text { microorganisms }\end{array}$ & Faecal samples & Litter & Soil \\
\hline \multicolumn{4}{|c|}{ Winter } \\
\hline Lactobacillus & $1,1 \pm 0,04 \cdot 10^{9}$ & $3,4 \pm 0,03 \cdot 10^{4}$ & $1,2 \pm 0,04 \cdot 10^{5}$ \\
\hline Enterococcus & $2,7 \pm 0,1 \cdot 10^{7}$ & $6,1 \pm 0,4 \cdot 10^{6}$ & $1,4 \pm 0,4 \cdot 10^{6}$ \\
\hline Bifidobacterium & $10^{8}$ & $10^{4}$ & $10^{4}$ \\
\hline $\begin{array}{c}\text { E.coli } \\
\text { Coliform bacteria }\end{array}$ & $\begin{array}{l}1,4 \pm 0,1 \cdot 10^{7} \\
3,3 \pm 0,3 \cdot 10^{5}\end{array}$ & $\begin{array}{l}1,8 \pm 0,3 \cdot 10^{5} \\
4,2 \pm 0,1 \cdot 10^{6}\end{array}$ & $\begin{array}{l}7,0 \pm 0,2 \cdot 10^{3} \\
8,6 \pm 0,2 \cdot 10^{5}\end{array}$ \\
\hline Bacillus & $2,6 \pm 0,1 \cdot 10^{5}$ & $8,3 \pm 0,5 \cdot 10^{6}$ & $1,5 \pm 0,08 \cdot 10^{7}$ \\
\hline \multicolumn{4}{|c|}{ Summer } \\
\hline Lactobacillus & $2,8 \pm 0,2 \cdot 10^{8}$ & $6,3 \pm 0,9 \cdot 10^{7}$ & $7,3 \pm 0,6 \cdot 10^{6}$ \\
\hline Enterococcus & $7,3 \pm 1,4 \cdot 10^{7}$ & $7,1 \pm 0,3 \cdot 10^{6}$ & $6,3 \pm 0,1 \cdot 10^{6}$ \\
\hline Bifidobacterium & $10^{7}$ & $10^{4}$ & $10^{4}$ \\
\hline $\begin{array}{c}\text { E.coli } \\
\text { Coliform bacteria }\end{array}$ & $\begin{array}{c}2,0 \pm 0,1 \cdot 10^{7} \\
-\end{array}$ & $\begin{array}{c}9,6 \pm 1,1 \cdot 10^{5} \\
-\end{array}$ & $\begin{array}{c}1,5 \pm 0,1 \cdot 10^{5} \\
-\end{array}$ \\
\hline Bacillus & $6,2 \pm 0,3 \cdot 10^{5}$ & $2,0 \pm 0,6 \cdot 10^{7}$ & $9,7 \pm 0,2 \cdot 10^{7}$ \\
\hline
\end{tabular}

Chickens from the private subsidiary plots of Rostov-on-Don in the winter period demonstrated a very high content of lacto and bifidobacteria $\left(1.1 \pm 0.04 \cdot 10^{9}\right.$ and $10^{8}$ $\mathrm{CFU} / \mathrm{g}$, respectively). In the summer period, their number, although it remained high, decreased by order of magnitude (to $2.8 \pm 0.2 \times 10^{8}$ and $10^{7} \mathrm{CFU} / \mathrm{g}$, respectively). Also, in the summer, the number of lactose-positive microorganisms decreased. We believe this is also due to changes in the diet in winter and summer. 
Bacteria from Bacillus genus of six morphotypes that did not change with the season, the total number of bacilli was $2.6 \pm 0.1 \cdot 10^{5} \mathrm{CFU} / \mathrm{g}$ in summer and $6.2 \pm 0.3 \cdot 10^{5} \mathrm{CFU} / \mathrm{g}$. In this case, we can also talk about colonization of the intestines of birds with isolated bacilli.

The litter's moisture content was $40 \%$ in winter and $48 \%$ in summer, soil $-43 \%$ in winter and $48 \%$ in summer. The number of lacto- and bifidobacteria in the litter and soil decreased by several orders of magnitude and enterococci by order of magnitude. There was also a significant decrease in BGKP. Those. The trend we noted in previous cases continued here as well.

Likewise, the litter and soil contained high numbers of free-living bacilli.

\section{Conclusion}

1. No dependence of the composition of chicken microbiota on the type of their maintenance was noted. Instead, it depends on the type of diet and the microbiota initially present in the farm environment. At the same time, the microbiota of birds can change at a young age, but after puberty, it becomes more stable. It can be assumed that young chickens receive the microbiota of older birds through the interaction with farm attendants or tools and later transfer it to the next generation.

2. The microbiota of free-range birds remained stable while maintaining diet and followed changes in diet depending on the season.

3. Litter and soil can maintain a sufficient supply of intestinal bacteria, which may facilitate microbiota exchange between birds and the retention of individual strains. It can become a problem if pathogens enter the litter or soil. Methods for correcting litter and soil microbiota should be considered separately and in detail.

4. Bacillus can colonize the digestive tract of birds, but a limited number of strains are adapted to do this. In general, Bacillus is not a permanent participant in the gut microbiota of birds.

Authors acknowledge the support of the Government of the Russian Federation (contract No. 075-152019-1880).

\section{References}

1. Paul, Poultry USA, 10(2), 16 (2009)

2. E. Terry, Poultry International, 47(8), 30-32 (2008)

3. H. R Haghighi, J. Gong, C. L. Gyles, et al., Clin. Vaccine Immunol., 13, 975-980 (2006), DOI: 10.1128/CVI.00161-06

4. J. T. Brisbin, J. Gong, S. Orouji, et al., Clin. Vaccine Immunol., 18, 1447-1455 (2011), DOI: 10.1128/CVI.05100-11

5. J. Gao, Md. A. K. Azad, H. Han, et al., Curr. Pharm., 26(22), 2630-2641 (2020), doi: 10.2174/1381612826666200211121916.

6. M. S. Makarenko, V. A. Chistyakov, A. V. Usatov, et al., Probiotics Antimicrob. Proteins, 11, 588-593 (2019), DOI: 10.1007/s12602-018-9440-9

7. X. Yang, K. O. Darko, Ya. Huang, et al., Cell Physiol. Biochem., 42(1), 306-318 (2017), doi: 10.1159/000477386

8. M. S. Mazanko, I. F. Gorlov, E. V. Prazdnova, et al., Probiotics Antimicrob. Proteins, 10, 367-373 (2018), DOI: 10.1007/s12602-017-9369-4 
9. G. M. Lessire, S. Mallet, J. F. Guillot, World. Poult. Sci. J., 62, 499-511 (2006)

10. J. R. Chambers, J. Gong, Food Res. Int., 44, 3149-3159 (2011)

11. H. K. Allen, T. B. Stanton, Annu. Rev. Microbiol., 68, 297-315 (2014), DOI: 10.1146/annurev-micro-091213-113052

12. L. Mancabelli, C. Ferrario, C. Milani, M. Mangifesta, et al., Environ. Microbiol., 18, 4727-4738 (2016), DOI: 10.1111/1462-2920.13363

13. S. Chen, H. Xiang, X. Zhu, et al., Animals (Basel), 8(6), 84 (2018), doi: 10.3390/ani8060084

14. N. N. Kamel, A. M. H. Ahmed, G. M. K. Mehaisen, et al, Int. J. Biometeorol., 61, 1637-1645 (2017), https://doi.org/10.1007/s00484-017-1342-0

15. R. Selvam, S. Suresh, M. Saravanakumar, et al., Pharmacognosy Res., 10, 1-8 (2018), https://doi.org/10.4103/pr.pr_138_17

16. F. Q. Zhao, Z. W. Zhang, J. P. Qu, et a., Cell Stress Chaperones, 19, 635-648 (2014), https://doi.org/10.1007/s12192-013-0489-9

17. L. H. Li, Y. Z. Xing, P. Wen, Y. Yu, C. C. Li, R. L. Huang, Instrumentation Mesure Métrologie, 18(3), 317 - 322 (2019)

18. E. Baril, L. Coroller, O. Couvert, et al., Food Microbiol. 32(1), 79-86 (2012) doi: 10.1016/j.fm.2012.04.011.

19. D. Stanley, R. J. Hughes, R. J. Moore, Appl. Microbiol. Biotechnol., 98(10), 4301-10 (2014), doi: 10.1007/s00253-014-5646-2.

20. V. Clavijo, M. J. V. Flórez, Poult. Sci., 97(3), 1006-1021 (2018), doi:10.3382/ps/pex359.

21. A. K. Saxena, M. Kumar, H. Chakdar, N. Anuroopa, D. J. Bagyaraj, J. Appl. Microbiol., 128(6), 1583-1594 (2020), doi: 10.1111/jam.14506

22. E. Sokolova, V. Orobets, O. Sevostyanova, et al., E3S Web Conf., 175, 03015 (2020), https://doi.org/10.1051/e3sconf/202017503015

23. N. Korostylev, E. Prazdnova, M. Mazanko, et al., E3S Web Conf., 203, 04016 (2020), https://doi.org/10.1051/e3sconf/202020304016

24. A. Refeld1, A. Bogdanova, E. Prazdnova, et al., E3S Web Conf., 210, 06017 (2020), https://doi.org/10.1051/e3sconf/202021006017 